\title{
POLÍCIA E JUVENTUDE: CONFLITOS, INCERTEZAS E (DES) CONFIANÇAS
}

\author{
Jonas Henrique de Oliveira ${ }^{1}$
}

\section{Introdução}

Para Lévi-Strauss (1949) a etnografia consiste na observação e análise de grupos humanos considerados em sua particularidade e visando a reconstituição, tão fiel quanto possível, da vida de cada um deles. A etnografia é um importante método de pesquisa utilizado pelos antropólogos. Revelar as particularidades dos grupos observados é importante porque leva este profissional a pensar as fronteiras, as certezas, incertezas, os diálogos e as negociações que frequentemente fazem parte do trabalho do antropólogo.

A relação entre a polícia e jovens no Brasil revela dados alarmantes sobre uma relação tensa e repleta de conflitos. Jovens e policiais partilham o cenário urbano com motivações diferentes. Para os policiais manter as coisas em ordem é a missão a ser cumprida. Os jovens, por sua vez, buscam vivenciar a cidade de maneira a experimentála em suas múltiplas possibilidades seja em suas tribos urbanas (Maffesoli, 2006) ou através da prática de esportes ou lazer.

É no cenário urbano que se desenrola a violência onde policiais e jovens são protagonistas de conflitos onde não há vencedores. Seja nas brigas entre torcidas organizadas de futebol, em incursões mal sucedidas de policiais em comunidades ou em confrontos nas ruas da cidade, o fato é que o conflito entre policiais e jovens vem ceifando vidas em muitas cidades brasileiras.

O objetivo deste trabalho ${ }^{2}$ é apresentar as (in) certezas do trabalho de campo com policiais militares por um lado, mas também analisar as relações entre jovens e policiais na cidade do Rio de Janeiro. Ter policiais militares como sujeitos a serem compreendidos através da pesquisa em antropologia é desafiador já que frequentemente associam o trabalho do antropólogo ao do jornalista. Daí surge o primeiro desafio para o

\footnotetext{
${ }^{1}$ Universidade Estadual do Piauí, Brasil.

${ }^{2}$ A pesquisa foi realizada em 2004 e teve como resultado a dissertação de mestrado "A Polícia e os Jovens: um estudo sobre histórias de vida, práticas corporativas e conflitos urbanos" defendida em 2005 no Programa de Pós-Graduação em Antropologia e Sociologia no Instituto de Filosofia e Ciências Sociais da Universidade Federal do Rio de Janeiro.
} 
pesquisador: como se desvencilhar de uma identidade e ao mesmo tempo explicar para os sujeitos da pesquisa o faz um antropólogo. Apesar de não ter como responder essa questão de imediato, acredito que o desenvolvimento do trabalho elucidará essa questão.

\section{O trabalho de campo: do formal ao informal}

No início do trabalho de campo não estava certo qual seria a melhor maneira de estabelecer o primeiro contato com os policiais. Tampouco qual a quantidade de entrevistas adequadas para que a pesquisa fosse considerada "científica". Também não estava certo se seria melhor solicitar autorização formal ou entrar em contato diretamente com os entrevistados. Como se nota, inúmeras incertezas pairavam sobre a melhor maneira de realizar a pesquisa e eu não dispunha de nenhum material que me orientasse nesse sentido.

Naquele momento, imaginamos que uma aproximação "informal" seria a melhor maneira de abordar os entrevistados, pois através de autorização dos comandantes dos batalhões para realizar entrevistas ou junto à Secretaria de Segurança Pública do Estado do Rio de Janeiro (SSP-RJ) corríamos o risco de esbarrar na burocracia, o que provavelmente atrapalharia o desenvolvimento da pesquisa ${ }^{4}$.

O trabalho de campo foi possível através da ajuda de contatos pessoais em diferentes redes de sociabilidade (universidades, amizades, familiares) que previamente entraram em contato com os policiais de suas redes e que me apresentaram como o "antropólogo que queria fazer uma pesquisa". Estes foram imprescindíveis, sem os quais dificilmente as entrevistas não seriam realizadas. Após cada entrevista eu solicitava que o policial me indicasse outro entrevistado que pudesse dar informações, tão preciosas quanto às dele, sobre a relação entre policiais e jovens na cidade do Rio de Janeiro. Deste modo, cheguei ao número de quatorze entrevistas em profundidade. Notei que através da rede de sociabilidade ${ }^{5}$, os entrevistados se sentiam mais seguros,

\footnotetext{
${ }^{3}$ Refiro-me ao pedido de realizar a entrevista diretamente com os policiais, sem o consentimento dos superiores hierárquicos. É interessante notar que muitos policiais recusaram conceder a entrevista sem o consentimento de seus comandantes.

${ }^{4}$ Anos mais tarde em outra pesquisa esse receio se mostrou infundado, já que solicitei autorização do comando da PMERJ para realizar a pesquisa nos batalhões de polícia e a autorização foi muito rápida. Tampouco sofri qualquer interferência em meu trabalho por parte de comandantes ou das autoridades policiais.

${ }^{5}$ Este grupo de mediadores era composto de nove pessoas, dois homens e sete mulheres. Apenas um pertence ao meu ciclo de amizade da universidade, os demais são familiares e amigos que não são da universidade.
} 
afinal de contas eu era apresentado como: "estudante", "amigo", "pesquisador", ou seja, identidades que permitiram atenuar a desconfiança em relação a mim ou a minha pesquisa.

O contato inicial com os entrevistados se dava por telefone, através do qual eu explicava o objetivo da pesquisa e os motivos que me levaram a realizá-la. Assim, se o entrevistado concordasse, marcávamos um encontro em data e horário estipulados por ele. Em todos os casos procurei me adequar ao horário do entrevistado, evitando, ao máximo, atrapalhar sua rotina.

Apesar desta entrada no campo ter se mostrado eficaz, as recusas foram inevitáveis, justificadas, na maioria das vezes, por falta de tempo. Em dois contatos que fiz pelo telefone, os policiais, sem qualquer explicação, afirmaram que não estavam interessados em participar da pesquisa. Existiu ainda um caso em que o entrevistado manifestou interesse em participar, mas pouco tempo depois disse que havia pensado melhor e desistiu justificando: "já vi muita gente se ferrar dando entrevista".

No trabalho policial a desconfiança possui um papel importante. Nas entrevistas, ela surge como uma aprendizagem atrelada ao "saber das ruas". Deste modo, os policiais aprendem a desconfiar de tudo que foge a regra. $\mathrm{O}$ olhar treinado aciona um estilo de policiamento onde jovens se tornam suspeitos em potencial dependendo do local de moradia, da cor, do estilo musical, das roupas que vestem e da técnica corporal que utilizam.

Por outro lado, nas entrevistas os policiais tinham muita vontade de narrar as próprias experiências com os jovens. De certo modo, estas proporcionaram o momento de serem ouvidos, de contar a própria versão da história em relação aos jovens, pois estão cientes que este público é extremamente crítico as práticas policiais. Algumas vezes, quando expliquei que já havia realizado pesquisa com jovens e que estes relataram suas experiências com a polícia, alguns entrevistados me interrompiam afirmando: "eu tenho certeza que eles falaram muito mal da gente". 


\section{Gravar ou não gravar?}

Pedir para gravar uma entrevista é sempre um processo tenso. Isso é especialmente verdade no caso de pesquisa com policiais militares. No universo policial, conquistar a confiança é importante antes de qualquer entrevista. Deste modo, o pesquisador precisa deixar claro quais são os objetivos da pesquisa e que somente ele terá acesso à narrativa do entrevistado e, acima de tudo, que ele não seria identificado. O problema é que na maioria dos casos o contato face a face se dava no momento da entrevista e durante poucas horas. Não havia tempo suficiente para que a confiança fosse estabelecida entre os sujeitos da pesquisa e o pesquisador.

Entretanto, antes de iniciar as entrevistas pedia autorização para gravá-las, o que, na maioria dos casos, foi recusada. Era possível perceber que a cada vez que pedia para gravar um silêncio tomava conta do ambiente. Mesmo cientes de que a pesquisa tinha finalidade acadêmica, a recusa em gravá-la foi recorrente ${ }^{6}$. Ao evitar a gravação, o que estava em jogo não era uma recusa em produzir qualquer informação sobre a relação entre a polícia e a juventude na cidade do Rio de Janeiro, mas a certeza de que as informações não deveriam "deixar vestígios".

$\mathrm{O}$ uso do gravador faz parte das técnicas de pesquisa qualitativa tradicionalmente utilizada pelos cientistas sociais na coleta de depoimentos orais. Contudo, no trabalho de campo com policiais a coleta de dados era uma ameaça ao anonimato dos entrevistados e colocava em dúvida a "confiança" fragilmente instaurada. Queiroz (1991) afirma:

O gravador também é fonte de inibição para determinados informantes que, ao contrário, podem aceitar o registro escrito; este, portanto, não é somente relegado aos 'cadernos de campo', porém continua existindo para entrevistas que não seria possível obter de outra forma.

As recusas de gravação das entrevistas fizeram com que eu repensasse a melhor maneira de abordar os entrevistados já que o uso do gravador causava constrangimento. Ainda no campo das incertezas, um profissional das ciências sociais me sugeriu para esconder o gravador nas entrevistas. Eu considerei que essa prática poderia colocar em risco toda pesquisa e minha idoneidade como pesquisador.

\footnotetext{
${ }^{6}$ Das 14 entrevistas realizadas, apenas quatro foram gravadas. Entretanto, mesmo nas entrevistas gravadas em alguns momentos o gravador foi desligado a pedido do entrevistado.
} 
Com o gravador desligado, as conversas eram mais descontraídas e não havia grande preocupação em relação às falas sobre os jovens. Algumas condutas violentas eram narradas sem qualquer preocupação. Por outro lado, nas entrevistas gravadas as narrativas eram com mais parcimônia e evitava-se criticar o governo, a política de Segurança Pública, os comandantes de batalhão e denunciar as condições de trabalho a que estão submetidos nas ruas; o foco destas entrevistas era o dilema que enfrentam para manter a ordem. Também focavam o quanto a interpretação da Lei algumas vezes prejudica o trabalho dos policiais nas ruas ${ }^{7}$.

Após cada entrevista buscava um local tranquilo onde fosse possível escrever tudo o que havia visto e ouvido no campo, buscando ser o mais fiel possível aos relatos dos policiais. Ao final do trabalho de campo, percebi que o fato de não ter gravado a maior parte das entrevistas se revelou um ponto positivo para os meus propósitos. Além do ambiente relaxado, compreendi que certas falas só foram possíveis porque o gravador estava desligado.

\section{Discursos cristalizados}

$\mathrm{Na}$ pesquisa foi possível constatar muitos "discursos cristalizados" sobre as experiências cotidianas dos policiais com os jovens. As avaliações feitas da polícia, da política de segurança pública estadual, do papel da polícia e, em alguns casos, a versão para a violência urbana carioca também eram muito semelhantes. $O$ fato de meu interesse não estar focado a priori em mortes, crimes, assaltos, estupros ou corrupção, assuntos que fazem parte do "repertório policial" surpreendeu grande parte dos entrevistados.

Naquela época, minha inexperiência me levou ingenuamente a acreditar que seria possível compreender as representações dos policiais sobre a juventude sem necessariamente tocar na violência, o que se revelou impossível. Percebi que de fato a "violência", com todas as aspas que essa categoria exige, faz parte dos muitos

\footnotetext{
${ }^{7}$ Foi o caso de um policial do $15^{\circ}$ BPM - Caxias, que presenciou o roubo de um cordão de ouro de uma senhora por dois "menores de rua" no Flamengo, Zona Sul da cidade do Rio de Janeiro. O entrevistado disse que a senhora havia the pedido ajuda, pois acabava de ter o cordão de ouro roubado. Este saiu correndo atrás dos menores e apanhou um deles com o cordão. Ao voltar para o local, a senhora já não se encontrava mais e o policial foi obrigado a soltar o menor, pois segundo a Lei "se não há vítima, não há crime". Perguntei o que ele havia feito com o cordão e ele disse que levou o cordão para o prédio onde suspeitava que a senhora trabalhava. Este caso é interessante porque o policial disse que quem presenciou a cena pensou que ele fosse ficar com o cordão, mas, por isso mesmo, ele fez questão de entregar.
} 
elementos constitutivos da experiência de ser policial na cidade do Rio de Janeiro. Deste modo, a violência constituía uma linguagem através da qual era possível compreender melhor os comportamentos de muitos policiais. Ao final de cada entrevista, perguntava o que o policial havia achado daquela experiência e alguns afirmaram que imaginavam que eu queria saber sobre outras coisas. Mesmo sem perguntar, narrativas relacionadas à violência urbana surgiram espontaneamente.

Alguns policiais tinham a expectativa de que as entrevistas servissem para denunciar as condições precárias a que são submetidos os policiais militares em uma cidade com altos índices de "violência", como é o caso do Rio de Janeiro. Situações como, armamentos enferrujados, coletes que estão fora do prazo de validade e salários defasados eram relatados por quase todos os policiais. Novamente minha identidade tinha sido colada a de jornalista, por mais que eu me esforçasse por me descolar desta.

Algumas narrativas converteram-se em verdadeiros instrumentos de críticas ao Governo Estadual, aos comandantes de batalhão e à estrutura social que não dá direitos iguais a todos. Isso explicava, em parte, a relutância em gravar as entrevistas, pois podiam denunciar sem se identificar. Alguns policiais tinham mesmo a expectativa de que aquele depoimento poderia interferir na realidade que estavam descrevendo.

\section{O percurso: o antropólogo e seus nativos}

As entrevistas foram realizadas em muitos bairros e em diversos ambientes, tais como: cabine policial, hospital, campo de futebol, igreja evangélica e numa confeitaria. Nessas idas e vindas, pude constatar que a maioria dos entrevistados não residia próximo aos batalhões que trabalhavam. Em alguns casos, costumavam residir em outro município.

Residir em outro município pode ser considerado uma estratégia que os entrevistados utilizam para evitar ao máximo serem identificados como policiais, pois o perigo de confronto aumenta quando são identificados. Muitos policiais residem em regiões com pouco policiamento e se valem de estratégias para aumentar a própria segurança e a de seus familiares. Nestas situações eles estão sozinhos e só podem contar com a própria sorte. Alguns policiais entrevistados residem em favelas ou no entorno e escondem as carteiras de polícia, ficando submetidos aos silêncios impostos aos moradores destes locais. 
Para realizar este trabalho foram entrevistados policiais de diferentes batalhões, inclusive cinco que estão lotados em batalhões localizados fora do município do Rio de Janeiro. Assim, um policial entrevistado está lotado no $34^{\circ}$ BPM - Magé, outro está lotado no $35^{\circ} \mathrm{BPM}$ - Itaboraí, há ainda um terceiro que está lotado no $15^{\circ} \mathrm{BPM}-$ Caxias e um quarto lotado no $12^{\circ} \mathrm{BPM}$ - Niterói e, por fim, um quinto policial que está lotado no $24^{\circ} \mathrm{BPM}$ - Queimados. O que estes policiais têm em comum com os demais é que todos os praças para complementar a renda familiar fazem segurança particular, pois dizem que não têm como sobreviver somente com o salário de policial. Dessa forma, pude entrevistá-los nos locais em que se encontravam fazendo segurança privada. Este serviço extra é realizado em locais como boates, prédios privados, casas noturnas, casas particulares, etc. Também nestes "extras", os policiais estão em constante movimento pela cidade, aumentando assim as possibilidades de contato com diferentes segmentos juvenis. Neste sentido, é importante perceber que a experiência que informa suas representações e práticas, também está marcada pelo serviço extra quando se encontram sem farda.

São os policiais mais novos na hierarquia militar que estão constantemente presentes nas ruas em contato direto com o "crime", maximizando as chances de confronto e, por consequência, de morte. Desse modo, são enfáticos ao afirmar que "a polícia é uma categoria em extinção". A situação em que vivem coloca-os em uma situação de constante stress, como relata um entrevistado:

\begin{abstract}
Quando você vê morte de polícia, um índice grande de morte de polícia é fora do serviço, na segurança ou então o cara trabalha na segurança um dia, e num bico no outro e quase não fica em casa. Aí o que vai acontecendo com o indivíduo? O indivíduo vai ficar socialmente e familiarmente uma pessoa estranha. Ele fica estranho com a família, com os amigos e com a sociedade. Ele acaba se descolando de um perfil social. Ele se individualiza. O grupo dele é só o grupo da polícia e isso causa uma dificuldade muito grande. Isso causa um trauma na família, afasta os amigos e há uma transformação muito grande. O envolvimento direto com essa coisa, a cabeça do indivíduo vai sofrendo uma mudança. Ele acaba se estressando, as necessidades vão crescendo e acaba nisso que a gente está hoje ${ }^{8}$.
\end{abstract}

Essa narrativa foi recorrente no discurso de muitos policiais militares. De fato, existe a ideia entre eles da necessidade de união entre os policiais para combater a violência de que são alvos. Assim, é comum andar em grupo para se protegerem da violência. Apesar de ser policial, o indivíduo por trás da farda convive com os mesmos problemas dos cidadãos comuns como violência, desemprego, roubos, homicídio, etc.

\footnotetext{
${ }^{8} 2^{\circ}$ Sargento, 45 anos. Corregedoria de Polícia. 24 anos de serviços prestados à PMERJ.
} 
Pode-se dizer que os policiais, buscando demonstrar a importância que têm para o funcionamento da sociedade, compartilham de uma espécie de "teoria do caos". Foi essa a ideia que utilizaram para reafirmar sua importância em manter as coisas em ordem e sob controle. Para muitos, se as atividades da polícia parassem por apenas um dia no Rio de Janeiro a "sociedade viraria um caos", explosões de violência tomariam conta da cidade e a barbárie reinaria.

De acordo com um entrevistado ${ }^{9}$, viveríamos um processo de total anarquia, pois haveria assaltos a bancos, assaltos a agências de turismo, ônibus queimados, assaltos a pedestres, a bandidagem descendo os morros, etc. Deste modo, os policiais enaltecem a importância da instituição policial ao mesmo tempo em que reforçam o modelo de polícia ostensiva e repressiva para a qual utilizar mais violência para combater à violência torna-se o modelo a ser seguido.

Neste momento volto a questionar se profissionais que atuam em uma cidade com altos índices de violência poderiam pensar em combater a violência de outra forma. Essa reflexão me fez pensar que esse mundo "exótico" abria-me a possibilidade de conhecer mais de perto aqueles que imaginava estarem tão longe. Contudo, esse trabalho me fez transformar o exótico em familiar e o familiar em exótico. Deste modo, fui me aproximando do pensamento da categoria que eu buscava compreender. Assim, com eles eu aprendi muito mais sobre mim mesmo.

\section{Juventude e polícia: espaços, (in) certezas e (des) confianças}

Bourdieu (1999), analisando a noção de espaço social, faz a seguinte consideração:

\footnotetext{
Na realidade, o espaço social é um espaço multidimensional, conjunto aberto de campos relativamente autônomos, quer dizer, subordinados quando ao seu funcionamento e às suas transformações, de modo mais ou menos firme e mais ou menos direto ao campo da produção econômica; no interior de cada um dos subespaços, os ocupantes das posições dominantes e os ocupantes das posições dominadas estão ininterruptamente envolvidos em lutas de diferentes formas (sem por isso se constituírem necessariamente em grupos antagonistas).
}

\footnotetext{
${ }^{9}$ Soldado, 36 anos. $34^{\circ}$ BPM - Magé. 6 anos de serviços prestados à PMERJ.
} 
Aqui procuro analisar as representações dos policiais militares acerca dos diferentes segmentos juvenis. Esta análise nos permite dizer que suas condutas variam significativamente caso se encontrem na Zona Norte ou na Zona Sul da cidade - que devem ser consideradas não apenas em suas dimensões geográficas, mas como espaços de relações sociais. Os policiais classificam e hierarquizam os jovens de acordo com o local que residem.

Os policiais militares compartilham de representações socialmente construídas sobre os jovens com outros grupos sociais. Nestas, há um predomínio de opiniões negativas em relação à juventude, onde na maioria das vezes os jovens são considerados um problema social. Nas últimas décadas, a juventude vem ganhando atenção dos cientistas sociais, sobretudo porque as mudanças culturais, políticas e econômicas ocorridas na sociedade brasileira tiveram grande repercussão entre os jovens.

Certamente a violência está entre as maiores preocupações dos cidadãos cariocas. Cotidianamente os jornais publicam cartas de leitores "indignados" cobrando soluções das autoridades responsáveis pela segurança pública na cidade do Rio de Janeiro. Apesar de a violência atingir a todos, é notório que certos grupos sociais estão mais vulneráveis que outros. Se somos iguais em relação à possibilidade de sofrermos violência, o fato é que uns são mais iguais que os outros.

Entre os jovens de uma maneira geral, a violência é um problema que atinge preferencialmente jovens moradores de favelas, negros e pobres quando comparados com jovens brancas, de classe média e moradores de áreas socialmente valorizadas. As pesquisas de Minayo (1993), Soares (1996), Cano (1997) e Ramos (2003) indicam essa tendência. Curiosamente, os policiais consideram os jovens autores de violência e poucas narrativas apontaram os jovens como vítimas de violência.

A preocupação da juventude carioca com a violência policial é outro problema bastante significativo. É o que revela a pesquisa: Jovens do Rio: circuitos, crenças e acessos, coordenada por Novaes e Mello (2002), onde sofrer violência policial destacou-se em $5^{\circ}$ lugar nas preocupações dos jovens cariocas. Relatos de experiências com a Polícia Militar aproximam as opiniões de jovens de diferentes grupos e classes sociais. Novaes (2003) afirma: 
Em qualquer grupo, todos têm algo a contar sobre a polícia. Os mais ricos contam que foram 'achacados' e dizem: 'tivemos que negociar'. O que, via de regra, termina em ter que 'molhar a mão do policial'. Os mais pobres, sobretudo, se forem negros, contam que foram humilhados. As jovens mulheres falam que foram paqueradas, seduzidas ou desrespeitadas. Os moradores das favelas, conjuntos habitacionais, periferias e vilas dizem que são sempre vistos como os maiores suspeitos.

A construção social da violência policial partilhada pelos jovens tem como base notícias veiculadas pelos meios de comunicação de massa. No entanto, situações vividas ou presenciadas seja pelos próprios jovens, por parentes ou amigos mais próximos, contribuem para que construam um repertório acerca da violência policial que informam práticas, condutas e maneiras de lidar com os policiais. Minayo (1999), analisando a construção da violência entre os jovens, observa:

\begin{abstract}
A noção de violência construída por um jovem é em parte retirada do que realmente acontece; da sua consciência de classe; da sua posição na sociedade; das suas interações sociais na escola, na família e com as mensagens da mídia; da sua experiência com esse fenômeno; do imaginário coletivo; e de como sua subjetividade processa e reage a esse conjunto de relações e estímulos. A consciência dos jovens sobre o fenômeno teria, portanto, o peso das ideias hegemônicas que criaram as estruturas imaginárias de relevância, do desenvolvimento de suas experiências enquanto grupo etário, estrato social, gênero e etnia, e também dos fatos concretos que acontecem com eles ou que presenciam.
\end{abstract}

As representações compartilhadas pelos policiais associam os jovens das camadas populares e moradores de favelas ao tráfico de drogas, enquanto os jovens de classe média são vistos como consumidores de drogas. Em suas narrativas fica evidente que o foco da repressão policial concentra-se no tráfico e não no consumo. Muitos entrevistados consideram a favela como foco de violência e marginalidade, o que nos leva a supor que o estigma atribuído à favela contamina seus moradores. $\mathrm{O}$ estudo de Rinaldi (2003) sobre a categoria "favelado" no Tribunal de Justiça do Estado do Rio de Janeiro, ajuda na compreensão dessa questão:

Ser morador de favela é trazer consigo a 'marca de perigo', é ter uma identidade social pautada pela ideia de pobreza, miséria, crianças na rua, família desagregada, criminalidade, delinquência. Tais imagens são realimentadas pelos veículos de informação, que trazem notícias sobre o 'morro' sempre do ponto de vista negativo, enfatizando o tráfico de drogas e a violência.

A narrativa de um entrevistado é bastante esclarecedora acerca das representações associadas à favela: 
Eu não estou dizendo que todo mundo que mora no morro é bandido, mas em minha opinião, quando o cara quer ter um futuro ele estuda, consegue um emprego, casa, até mesmo com uma menina de dentro do morro e sai do morro. Casa e sai porque aquilo ali não é futuro para ninguém. ${ }^{10}$

A narrativa aponta para a favela como um local inadequado para se viver. Essa opinião é compartilhada por muitos entrevistados. Além de revelar representações estereotipadas, a fala assinala para um discurso criminalizante em relação a seus moradores. Por outro lado, há o "discurso da ausência" no qual a favela é pensada pela falta de saneamento básico, infraestrutura, segurança, ou seja, ela é frequentemente representada como um espaço "excluído". Esse pensamento expressa o tipo de presença do Estado nessas áreas, onde os serviços urbanos e sociais são precários e a violência policial uma prática comum. Zaluar (1985) constata que:

É sobre os pobres que a polícia concentra seu poder fortalecido nos últimos vinte anos: comete injustiças nunca pensadas, humilha, mata, tortura e, na rua, 'vai logo dando sugestão'. A desconfiança que a presença policial desperta entre eles, mesmo quando concordam sobre a necessidade do policiamento ostensivo e sobre os bons propósitos de alguns (poucos) policiais, é notável. A memória de muitos casos adversos e trágicos mantém a imagem negativa do policial. Por isso dizem preferir, entre o policial e o bandido, a este último, que conhecem e com quem podem conversar.

Nas narrativas dos policiais, os jovens das classes populares são identificados como traficantes e bandidos e os jovens da classe média são considerados consumidores de drogas. É interessante notar que essas classificações são arbitrárias. Contudo, essa arbitrariedade encontra sentido na experiência dos policiais que atuam com os jovens.

Destarte, os policiais dividem simbolicamente a cidade do Rio entre Zona Norte e Zona Sul. A primeira é classificada pelo excesso de tráfico e a segunda pelo excessivo consumo de drogas. Os policiais compartilham a opinião que o tráfico de drogas deve ser combatido e reprimido, mas se consideram incapazes de reprimir o consumo, pois na maioria das vezes "não adianta nada" e, por isso, sentem que estão "enxugando gelo".

A rua é, na ótica dos policiais, o local de "manutenção da ordem" e, por conseguinte, de demonstração de autoridade ${ }^{11}$. Entretanto, para os jovens que transitam

\footnotetext{
${ }^{10}$ Soldado, 30 anos. $3^{\circ}$ BPM - Méier, 6 anos de serviços prestados à PMERJ.

${ }^{11}$ Certa vez, parei com um grupo de amigos em um bar na Lapa, próximo a ele havia uma viatura da PMERJ. Este bar era pequeno e havia algumas mesas na calçada. Estávamos conversando sobre vários assuntos, quando observei um sargento discutindo com o garçom do bar onde estávamos. A discussão girava em torno das mesas que estavam na calçada, pois o policial argumentava que elas não poderiam estar naquele lugar. Então o sargento disse ao garçom: “- Olha! Eu vou dar uma volta, quando eu voltar
} 
nos variados circuitos disponíveis de lazer que a cidade oferece a rua é um espaço que permite maior exercício da liberdade. Nas últimas décadas, com o progressivo aumento da violência novos arranjos e estratégias são utilizados pelos jovens para transitarem em segurança pela cidade.

Como se sabe, uma das características que definem a condição juvenil é "estar em grupo". Foracchi (1972), em relação à juventude moderna, observa: "há uma forte valorização da experiência comum, dos valores comuns, da identificação mútua que vincula os jovens à vida grupal". Estar em grupo pode ser considerada uma estratégia dos jovens de diferentes camadas sociais para evitar a violência em geral e permitir que transitem pela cidade com mais segurança.

Por outro lado, em grupo os jovens também se tornam "suspeitos preferenciais" e alvos frequentes das abordagens policiais. As imagens associadas aos jovens em grupo revelam que estes são considerados mais violentos. Para os policiais, em grupo os jovens são mais ousados, praticam delitos que dificilmente cometeriam sozinhos. Em alguns casos os jovens são motivados pelo grupo a assaltar, roubar, envolver-se em brigas, pancadarias, etc.

Nas entrevistas, ouvi de muitos policiais que dificilmente um jovem assalta sozinho, fuma maconha sozinho, troca tiros com o policial sozinho. No cotidiano da cidade, jovens em grupo são confundidos com bandidos e, por isso, costumeiramente abordados. Assim, as rondas policiais elegem, classificam e abordam jovens em grupo sem nenhum motivo aparente. A lógica da suspeição possui regras próprias que não são acessíveis a todos os grupos.

Evidentemente não são todos os jovens "em grupo" que são parados pela polícia. Somente aqueles que trazem marcas sociais que os identifiquem, na ótica policial, como perigosos. Este sinal diacrítico - facilmente lido pelos policiais - aciona um rígido mecanismo de repressão. Fatores como horários, proximidade a favelas e aparência (maneira de vestir, andar, falar, gesticular, etc.) são de grande relevância nesta classificação e hierarquização.

Os policiais entrevistados percebem que na Zona Sul os jovens não têm respeito e são tratados com menosprezo. Naquele espaço social se sentem vulneráveis, dizem

não quero ver nenhuma mesa na calçada." Uma menina que se encontrava próxima ao garçom e ao sargento tentou argumentar dizendo que as mesas não estavam atrapalhando ninguém, mas o policial disse: “... aqui quem manda sou eu, já disse que não pode e ponto final." O garçom pediu a todos os clientes que estavam nas mesas que pagássemos a conta e que não poderia fazer nada, pois era "ordem do policial." 
que não possuem instrumentos para reprimir certos crimes. Sabem que os jovens, possuem uma rede sociabilidade e dificilmente serão condenados por consumo de drogas. Nesses casos, é melhor "fingir que não vê" o consumo de drogas por terem certeza da impunidade dos usuários.

Bretas (1995) em sua análise sobre a polícia carioca no início do século passado, já havia notado que a atuação policial variava dentro de um repertório de opções dentro e fora da legalidade:

O policial tem como expectativa, sempre, o comportamento legal, que aprendeu a valorizar, embora reserve para si um repertório de opções fora da legalidade, das quais lança mão de acordo com sua visão dos "fatos". Numa forma simplificada, podemos dizer que o leque de opções abrange da decisão de não intervir, não ver o que se passa, até o emprego da violência. A seleção do procedimento se faz através de um conhecimento organizacional - não ensinado nas escolas - que, em última instância, qualifica a cidadania dos envolvidos, através de valores atribuídos a cor, idade, sexo, nível socioeconômico, etc.

Velho (1973) constatou haver uma hierarquia entre os bairros localizados na cidade do Rio de Janeiro. De acordo com os seus informantes, os bairros situados na Zona Sul são considerados modernos, enquanto que os bairros da Zona Norte são considerados atrasados. O bairro de Copacabana, onde o autor concentra sua análise, é considerado um dos mais modernos da Zona Sul carioca. Entre as justificativas desta "modernidade" atribuída a Copacabana um informante afirmou que ali é um bairro de pessoas que "venceram na vida". Ou seja, local que demonstra um projeto de vida bem sucedido. A Zona Sul moderna se encaixa no modelo de modernidade onde o consumo de drogas faz parte de um estilo de vida que seus jovens moradores fazem questão de demonstrar. Por outro lado, na Zona Norte impera o tráfico, a desordem e o caos na percepção dos policiais.

A hierarquia dos bairros reflete de modo bastante singular as diferenças nas representações e ações dos policiais que separam, hierarquizam e possuem condutas diferenciadas para os jovens moradores da Zona Norte e da Zona Sul. Assim, se o estigma atribuído aos moradores dos subúrbios e favelas contamina seus moradores, da mesma forma, o status atribuído à Zona Sul contamina seus moradores. É justamente nesse espaço social que os serviços públicos são mais eficazes.

Nas imagens veiculadas pela mídia, a Zona Sul representa um estilo de vida legítimo e um padrão a ser seguido por toda a cidade. As belezas naturais se concentram em grande parte ali (Pão de Açúcar, Corcovado, praias). Dessa forma, a Zona Sul 
tornou-se - devido ao status que possui - um espaço onde as políticas públicas em geral ganham mais visibilidade. Pode-se mesmo dizer que a representação da Zona Sul tem influência direta nas ações e práticas dos governantes para aquela região. O que faz com que ali seja um local privilegiado por políticas públicas. Isso se reflete nas políticas de Segurança Pública Estadual, pois é justamente naquele espaço que há uma maior concentração de policiais militares por habitante, apesar de não ser este um espaço com altos índices de crimes violentos quando comparados com outras regiões da cidade.

O fato de a Zona Sul concentrar a população com um maior nível de renda, também influencia na atitude dos governantes. O que estou propondo aqui é que certos serviços públicos tais como: segurança, iluminação, saneamento básico, saúde, etc. são encontrados ali com muito mais facilidade do que em outras localidades da cidade, há uma maior preocupação com os moradores daquele segmento social que com moradores de outras regiões da cidade.

Nesta perspectiva, DaMatta (2000) chama a atenção para o fato de que: "No Brasil, por contraste $\left[\right.$ aos Estados Unidos] ${ }^{12}$, a comunidade é necessariamente heterogênea, complementar e hierarquizada. Sua unidade básica não está baseada em indivíduos (ou cidadãos), mas em relações e pessoas, famílias, e grupos de parentes e amigos". De acordo com um entrevistado ${ }^{13}$ :

Os jovens de classe média a polícia trata diferente sim, até porque na Zona Sul o jovem pode ser filho de desembargador, filho de coronel, filho de juiz, filho de promotor. Então, se o policial dá um tapa ele vai se ferrar, a gente tem que ter o maior cuidado, agora na favela muitos policiais batem, dão esculacho, eu acho que isso acontece porque os jovens não sabem dos seus direitos, não têm acesso à educação, porque se tivessem, se soubessem os seus direitos, o policial não ia fazer o que faz.

$\mathrm{Na}$ tentativa de inocentar os jovens moradores das favelas, o policial responsabiliza os jovens que "não sabem dos seus direitos, não têm acesso à educação". Todavia, o entrevistado reconhece que a polícia trata diferenciadamente jovens de "classe média". Assim, é possível afirmar que a posição de classe, com suas redes de sociabilidade definidas favorecem os jovens de classe média e ao mesmo tempo impõe uma dura rotina aos jovens das classes populares.

\footnotetext{
${ }^{12}$ Grifo meu.

${ }^{13}$ Soldado, idade não revelada. $15^{\circ} \mathrm{BPM}$ - Caxias, 9 anos de serviços prestados à PMERJ.
} 


\section{Jovens da Zona Sul}

Os jovens da Zona Sul são considerados sem limites. Para os policiais, os pais são culpados pelas atitudes dos filhos. $\mathrm{O}$ fato de terem dinheiro, casa própria, educação de qualidade, etc, não é suficiente para um controle das atitudes dos jovens, porque mesmo tendo isso não têm "estrutura familiar". Entre as atitudes consideradas sem limites podemos destacar: a queima de mendigos nas ruas, a quebra de orelhões públicos, as brigas de grupos rivais; podendo evoluir para atitudes consideradas mais graves como roubo a pedestres e de carros.

Alguns policiais constataram que nos dias atuais existe uma "completa inversão de valores" que pode ser verificada quando um jovem é conduzido para a delegacia ao ser flagrado consumindo drogas. Logo que os pais chegam à delegacia, eles buscam justificar a atitude do filho dizendo: "mas maconha é uma droga leve", os policiais contestam "droga leve é droga". Deste modo, muitas vezes os jovens não têm noção que a maconha dele, com a maconha de outro jovem e assim por diante, fortalece o tráfico de drogas e, portanto, contribuem para o aumento da violência.

Outro exemplo da "completa inversão de valores" sociais foi dado por um oficial $^{14}$ que afirmou ser comum o consumo de drogas nas praias cariocas. De acordo com este oficial, as praias são preferidas porque nelas os jovens podem "fumar maconha com amigos", exercitando assim sua liberdade individual. Nas praias é possível observar os policiais a metros de distância, o que facilita esconder a droga na areia e assim se livrarem do flagrante. Os policiais afirmam que para se livrar do flagrante alguns comem a droga. Há ainda, policiais que acreditam que a própria legislação brasileira favorece o tráfico de drogas ao reconhecer este como crime, mas não o consumo.

No discurso dos policiais, algumas instituições são responsáveis pela educação dos jovens e por repassar valores necessários para que estes não se envolvam em "coisas erradas”. Nesta linha de raciocínio, a família é a responsável por manter os jovens sob controle. Percebe-se claramente a ideia de "desestrutura familiar" - à medida que as figuras paternas e maternas não mais oferecem modelos de comportamento para seus filhos. Na maioria dos casos, os pais dos jovens de classe média são responsabilizados

\footnotetext{
${ }^{14} 2^{\mathrm{o}}$ Tenente, 29 anos de idade. $2^{\circ} \mathrm{BPM}$ - Botafogo, 5 anos de serviços prestados à PMERJ.
} 
quando não têm tempo para cuidarem dos filhos, transferindo, dessa forma, suas responsabilidades para escola.

No ponto de vista dos policiais entrevistados, o excesso de tarefas que os pais de jovens de "classe média" imputam aos seus filhos é um erro. Na tentativa de preencher a falta de tempo, os pais procuram ocupar ao máximo o cotidiano de seus filhos, pagando aulas de inglês, natação, ginástica, cursos diversos; mas investem pouco no convívio familiar. Como os pais dos jovens de "classe média" não têm tempo para "vigiar" se os seus filhos estão realmente realizando as atividades que financiam.

As brigas podem ser consideradas outra característica dos jovens. Muitos fatores concorrem para estimulá-las, a competição por mulheres parece ser um dos motivos mais comuns. Se um jovem paquera a namorada de outro - rompendo fronteiras imaginárias simbolicamente construídas pelos jovens que dividem e classificam o espaço dos bailes - ou "olha atravessado" já é motivo para brigar. O interessante é que as brigas são utilizadas para marcar as diferenças entre a geração atual e a dos entrevistados. Apesar de encararem as brigas como comuns na época em que eram jovens, os policiais disseram que gostavam de ir aos bailes "arranjar mulher" e, atualmente, os jovens já saem de casa com a intenção de brigar. Dois grupos de jovens foram muito lembrados pelas brigas que se envolvem: os pitboys e os funkeiros. Evidentemente a repressão policial se faz mais presente no segundo grupo.

Sobre as "galeras funk" no Rio de Janeiro, Cecchetto (1997) afirma que: "nos bailes onde as galeras exibem os padrões de violência acima mencionados, as fronteiras entre o jogo e o conflito, entre a competição e a destruição, tornam-se difusas, ultrapassando os muros dos bailes para fazer parte do cotidiano dos jovens em várias atividades, inclusive a escola".

A declaração de um policial fornece argumentos de como o espaço influencia no tratamento dos policiais aos diferentes grupos que circulam pela cidade:

Os jovens da Zona Sul, os famosos pitboys, esses só fazem arruaça na Zona Sul, vê se você houve falar em pitboy aqui na Zona Norte, na Penha, em Olaria, em Ramos? Aqui é subúrbio meu amigo, aqui o buraco é mais embaixo, se um pitboy desses parar na minha frente na Zona Norte, eu encho ele de bala. Veja só, eu sou baixinho, uso óculos, na mão não tem como fazer, então, eu nem penso duas vezes, encho ele de bala. Mas na Zona Sul não, ele pode ser filho de um desembargador e aí a coisa complica. $^{15}$

\footnotetext{
${ }^{15} 2^{\circ}$ sargento, 37 anos, $18^{\circ}$ BPM - Jacarepaguá, 18 anos de serviços prestados à PMERJ.
} 
A narrativa confirma que o tratamento aos grupos de jovens depende do espaço em que se encontram. Notemos que as brigas também ocorrem em grupo. É mais comum que elas ocorram em grupo e entre grupos rivais. A violência que as brigas exprimem pode ser entendida como uma espécie de divisão simbólica da cidade pelos grupos de jovens. Os grupos se reconhecem pelos bairros que moram e pelas atividades de lazer que praticam (skate, surf, rock, hip-hop, funk, etc.).

Em menor número, mas nem por isso menos importantes, surgiram depoimentos associando jovens de classe média a crimes como roubo a bancos, a carros importados, a pedestres, etc. No entanto, esses crimes eram todos relacionados ao vício das drogas. Outro ponto comum aos policiais que entrevistei é a visão hedonista que costumam fazer dos jovens de classe média. O consumo de drogas (lícitas e ilícitas) seria mais um caminho na busca pelo prazer.

Não por acaso, muitas narrativas apontam os jovens desta geração como sem ideais, sem perspectivas, sem horizontes, sem rumo, sem futuro, etc., ou seja, a atual geração é pensada pelo que perdeu em relação à geração anterior. Assim, podemos deduzir que os policiais manipulam a categoria juventude de acordo com seus interesses e com a visão de mundo que construíram a partir de um contexto socialmente definido.

Alguns policiais concentraram suas reflexões sobre a juventude atual, a partir do que ela não possui (horizontes, rumo, futuro, etc.), quando comparada com a geração que lhe antecedeu ou a dos entrevistados. Essas reflexões confirmam que cada geração de fato possui marcos geracionais específicos que orientam a percepção sobre a geração que a sucedeu ou antecedeu, possibilitando dessa forma a comparação entre elas.

\section{Jovens da Zona Norte}

É sobre este segmento da juventude que os policiais concentram suas ações. Se afirmam estar de mãos amarradas para lidar com os jovens de classe média que consomem drogas, em relação aos jovens das favelas e subúrbios esses discursos não são comuns. Muitos entrevistados preferem lidar com os jovens moradores das favelas e subúrbios a lidarem com os jovens de classe média e moradores da Zona Sul. Segundo um entrevistado ${ }^{16}$,

\footnotetext{
${ }^{16}$ Soldado, 29 anos. $24^{\circ}$ BPM - Queimados, 6 anos de serviços prestados à PMERJ.
} 
Os jovens na Zona Norte respeitam mais, quando nós os mandamos parar, eles respeitam logo. Os jovens da Zona Sul não, eles não respeitam muito, tratam com arrogância o policial, talvez pelo fato de terem dinheiro e saberem que não vão ficar presos.

Em relação à atuação dos policiais na Zona Norte e na Zona Sul da cidade, Sansone (2002) afirma:

Na Zona Norte do Rio de Janeiro, predominantemente de classe baixa, o policiamento é mais rude, e resulta na morte de um número muito maior de pessoas do que na Zona Sul, mais rica. Na primeira, as pessoas são mais pobres, porém o clima geral de ilegalidade oferece mais oportunidades para formas de corrupção em pequena escala, e as atividades escusas paralelas - um acréscimo fundamental aos magros salários dos PMs. Na Zona Sul, ao contrário, o policiamento é muito menos violento e, por conseguinte, menos perigoso para os próprios PMs; porém, é mais difícil conseguir propinas, porque as pessoas tendem a ser mais assertivas e mais difíceis de intimidar - 'temos que tomar cuidado, porque a gente pode parar um sujeito e descobrir que ele é juiz ou filho de um juiz!’.

A preferência em lidar com os jovens moradores da Zona Norte é justificada porque "os jovens respeitam mais". No entanto, um entrevistado ${ }^{17}$, avaliando a atuação da polícia na Zona Norte, observa que:

O comportamento dos policiais quando estão na Zona Sul é bem diferente de quando estão na Zona Norte. Na Zona Sul eles dizem não senhor e sim senhor, mas na Zona Norte, eles entram invadindo, arrombando portas e pronto. Eu sei que é errado, mas é assim que acontece.

A experiência de policiar as ruas da cidade faz emergir muitos discursos. Dentre eles, alguns policiais acreditam que a experiência em atuar em favelas faz com que eles digam saber "identificar" trabalhadores e bandidos. De acordo com suas definições arbitrárias do "suspeito em potencial", os policiais identificam, classificam, separam e punem os possíveis "bandidos" que ali residem. Se houver dúvida, prontamente a carteira de trabalho é retirada do bolso para atestar a idoneidade do morador. Seguramente por isso a carteira de trabalho "assinada", nas favelas e subúrbios, é tão importante.

Rinaldi (2003) ajuda a entender essa questão:

Em certas falas, esses profissionais afirmam que nem todos os favelados são marginais; que ter contato com eles não oferece perigo; que existem favelados honestos e trabalhadores. O que permanece, no entanto, é que toda a vez que procuram negociar a identidade de favelado, o ponto de partida é o estigma, o lugar

\footnotetext{
${ }^{17}$ Idem.
} 
da 'anormalidade', da anomia, da carência. Por isso, mesmo quando se usam símbolos de prestígio, tais como uma folha penal limpa e uma carteira de trabalho, permanece a categorização mais geral acerca desse grupo. Favelado continua sendo 'marginal', e os que não confirmam a regra são exceção.

O tráfico de drogas é o crime mais atribuído aos jovens das favelas e dos subúrbios cariocas ${ }^{18}$. Dentre as muitas explicações para o envolvimento dos jovens das favelas com o tráfico está a de ser esta uma atividade onde se movimenta muito dinheiro e se "ganhar dinheiro fácil". Ainda sobre este assunto, um entrevistado observa:

Então veja o caso da Rocinha, lá não tem saneamento básico, não tem projetos sociais, não tem auxílio do Estado e ao mesmo tempo o jovem tem a família grande, o pai morreu, está desempregado ou ficou no nordeste. Ao mesmo tempo tem a figura do traficante, que começa pedindo ao jovem para buscar uma coca-cola, depois um pão com mortadela; ele vê as pessoas respeitando o traficante e chamando-o de 'senhor fulano de tal', depois ele vira avião, mula, soldado e quem sabe chega a gerente, isso se sobreviver até lá.

Na opinião deste entrevistado, o Estado não fornece as condições necessárias para que os jovens possam desenvolver suas habilidades. Em sua opinião, o tráfico acaba sendo um caminho natural aos jovens que não tiveram oportunidades na vida.

O respeito atribuído ao chefe do tráfico de drogas, na visão dos policiais, pode ser um estímulo à entrada dos jovens para o tráfico. Este respeito traz consigo outros elementos importantes, que vão influenciar na entrada dos jovens para o tráfico. Ouvi de muitos policiais que os traficantes conseguem as melhores mulheres da comunidade. Assim um entrevistado ${ }^{19}$ afirma:

Esse pessoal que entra no tráfico porque vão conseguir as melhores mulheres, tênis de marca, respeito dentro do local em que moram, então eles acabam sendo referencial para outros meninos. Eu estou cansado de ver nos julgamentos, que participam mulheres lindas que estão com esses jovens, muitas vezes eles são malcheirosos, porque não tomam banho, mas mesmo assim têm quatro, cinco mulheres dentro da favela. Então eles saem de uma casa e vão para outra sem tomar banho. $\mathrm{O}$ que eu sinto nesses jovens é que eles têm pressa de viver, muitos sabem que a vida é curta, que vão morrer rápido, então eles têm pressa de viver. Vivem intensamente, mas não têm tempo para tomar banho, aproveitam cada minuto da vida como se fosse o último. ${ }^{20}$

\footnotetext{
${ }^{18}$ Sobre o assunto, ver Sento-Sé (2003).

${ }^{19} 2^{\circ}$ Sargento, 37 anos de idade. $18^{\circ} \mathrm{BPM}$ - Jacarepaguá, 18 anos de serviços prestados à PMERJ.

${ }^{20} 2^{\circ}$ sargento. 38 anos de idade. $18^{\circ} \mathrm{BPM}$ - Jacarepaguá, 18 anos de serviços prestados à PMERJ.
} 
Alvito (2001) esclarece a importância de ter várias mulheres para os traficantes:

Sendo assim, aquilo que a mídia compara a um harém - emprestando à favela um exotismo oriental - e, além de uma demonstração de poder, prestígio e virilidade, uma estratégia conscientemente percebida. Ter várias mulheres significa ampliar a rede de parentesco e, também, de solidariedade. Multiplicam-se assim as casas onde abrigam-se por algumas horas ou por uma noite; os locais onde esconder armas e drogas.

Na percepção dos policiais é possível perceber a associação entre pobreza, consumo e poder. Juntos, estes fatores apontam as causas mais comuns que estimulam os jovens pobres a entrar para o tráfico de drogas. Porém, alguns policiais atribuem parte da culpa aos governos municipal, estadual e federal que não investem em educação e em melhorias na condição de vida dos moradores das favelas.

Em muitas entrevistas, os policiais fizeram questão de mostrar que estão insatisfeitos com a política de segurança pública. Era comum a crítica que o governo estadual investe em armas, em viaturas, mas não investe no ser humano que está portando a arma ou dirigindo a viatura. Dessa forma, demonstram que não há investimentos nos policiais, seja em capacitação, em melhorias nas condições de trabalho ou melhores salários. Apesar da revolta com a situação em que vivem, muitos se sentem orgulhosos do seu papel social, afinal de contas, são eles que mantêm as "coisas em ordem".

Se os policiais mais velhos, ancorados em sua experiência, acreditam saber identificar trabalhadores e bandidos nas favelas; outros policiais, sobretudo os mais novos, consideram que na favela não se sabe "quem é do bem" e "quem é do mal". A partir dessas classificações elaboram frases como: "antes a tua mãe chorar que a minha".

Eu acho a juventude hoje em dia imatura, impulsiva; o jovem hoje em dia não tem responsabilidade, então muitos acabam entrando para o tráfico. Eu não posso considerar um garoto de 12 anos que segura um fuzil ou uma faca um jovem. Então o jovem é alienado, porque não vê o dado com outras direções. Eu não digo nem a moeda que só tem dois caminhos, mas o dado com outras direções. ${ }^{21}$

Conforme os entrevistados, na estrutura do tráfico existem inúmeras divisões, que refletem a hierarquia comum ao tráfico de drogas nas quais os jovens se inserem. Existem olheiros, soldados, mulas, gerentes, aviões, etc. Os olheiros - jovens que

\footnotetext{
${ }^{21}$ Soldado, 30 anos. $3^{\circ} \mathrm{BPM}$ - Méier, 6 anos de serviços prestados à PMERJ.
} 
observam a movimentação dentro da favela e avisam aos demais traficantes sobre a presença da polícia - costumam estar desarmados, e por isso têm menos chances de morrer. Já os soldados - responsáveis pela defesa da boca de fumo - têm, no confronto direto com os policiais, mais chances de matar ou de morrer. Nas operações policiais, na maioria das vezes, inexiste por parte dos policiais militares qualquer preocupação se os jovens que trocam tiros serão mortos.

No livro A letalidade da ação policial, Cano (1997) conclui:

O número de vítimas fatais é maior nas intervenções nas favelas da cidade. Em contrapartida, o número de feridos é superior nas intervenções no asfalto. Consequentemente, a letalidade das atuações policiais nas favelas é mais de duas vezes superior à de suas ações no asfalto. No entanto, os confrontos dentro das favelas parecem representar um risco comparativo menor para os próprios policiais, e um risco menor também para as vítimas acidentais (balas perdidas).

De fato, a atuação do policial no asfalto é diferente da sua atuação nas favelas; da mesma forma que a sua atuação na Zona Sul é diferente de quando estão atuando na Zona Norte. No asfalto, como revela Cano, o número de feridos é superior, revelando que ali a letalidade da ação policial é menor se comparado às favelas, onde o número de mortes é superior ao número de feridos. Os policiais que eu entrevistei, não demonstraram qualquer preocupação com o número elevado de mortes dentro das favelas, apesar de reconhecerem que ali "não existem somente bandidos".

A partir das falas dos entrevistados, podemos perceber que nas favelas os policiais se eximem da culpa, pois consideram que em uma atividade criminosa como o tráfico de drogas, onde é constante o confronto com a polícia, as mortes dos bandidos são normais. Os policiais "estavam fazendo o seu trabalho" e compartilham a ideia que "bandido bom é bandido morto".

\section{Considerações finais}

Este trabalho teve como intenção apresentar alguns dilemas que os antropólogos enfrentam ao realizar uma pesquisa de campo com policiais militares. Assim, procurei compreender suas narrativas e o sentido que dão as suas ações em seus próprios termos. Entretanto, procurei apresentar dilemas que enfrentam para realizar o trabalho de policiamento. 
Uma pesquisa de campo com policiais requer uma negociação intensa com a realidade, sobretudo porque o antropólogo frequentemente é confundido com jornalista que na percepção policial apenas busca vender jornal e apresentar as falhas da atividade policial, mas não retrata o lado bom da polícia.

A relação entre jovens e policiais no Rio de Janeiro é repleta de conflitos. Muitos destes tendo os policiais como autores e como vítimas. Sabemos que a atividade policial é perigosa e, por isso, mesmo a desconfiança é um elemento central que muitas vezes livra o policial do perigo. É justamente aí que realizar o trabalho se mostrou complicado. Ser confundido com jornalista é o menor dos problemas que um antropólogo pode enfrentar. Recordo-me que certa vez fui confundido por um entrevistado com um traficante de drogas. Para a minha sorte este traficante estava preso e, por isso, não fui tratado com desrespeito pelo entrevistado.

Durante cinco meses tive a oportunidade de conviver com policiais. Revendo os dados da pesquisa me questionei se a maneira que escolhi foi a melhor. Contudo, quando se escolhe um caminho algumas vezes não se pode voltar. O que se pode é andar em frente e pensar o passo seguinte sempre tendo clareza que outras opções são possíveis. Avançar, retroceder e negociar com a realidade são formas de se aproximar do grupo que se deseja compreender.

O universo policial é repleto de significados. Compreender essa categoria tão importante na sociedade moderna requer paciência. Entretanto, depois de anos tenho certeza que com eles aprendi mais sobre mim e sobre os dilemas de quem vive em uma sociedade plural, desigual, violenta e multifacetada.

\section{Referências}

ALVITO, M. As cores de Acari: uma favela carioca. Rio de Janeiro: Editora FGV, 2001. ARIÈS, P. História Social da Criança e da Família. Rio de Janeiro: Editora Guanabara, 1986. BOURDIEU, P. O poder simbólico. Bertrand Brasil. $3^{\circ}$ edição. Tradução Fernando Tomaz, 1999.

BRETAS, M. L. A guerra das ruas: povo e polícia na cidade do Rio de Janeiro. Rio de Janeiro: Arquivo Nacional, 1997.

CANO, I. Letalidade da Ação Policial no Rio de Janeiro. Rio de Janeiro: ISER. P. 80. 1997.

CECCHETTO, F. As galeras funk cariocas: entre o lúdico e o violento, in: Galeras Cariocas. Vianna, H. (org). Editora UFRJ, 1997

DaMATTA, R. Carnavais, malandros e heróis: para um paradigma do dilema brasileiro. $6^{\mathrm{a}} \mathrm{ed}$. Rio de Janeiro: Rocco, 1997. 
A casa e a rua. $5^{\text {a }}$ ed. Rio de Janeiro: Rocco, 2000.

FORACCHI, M. A Juventude na Sociedade Moderna. São Paulo: Livraria Pioneira Editora. 1972.

LÉVI-STRAUSS, C. Etnologia e História. In: Antropologia Estrutural I. Tempo Brasileiro, 1949.

MAFFESOLI, M. O tempo das tribos: o declínio do individualismo nas sociedades de massa. 4ed. Rio de Janeiro: Editora Forense 2006.

MINAYO, M. C. S. (et al.) Fala Galera: juventude, violência e cidadania na cidade do Rio de Janeiro. Rio de Janeiro: Garamond, 1999.

\& SOUZA, E. R. Violência para todos. Cadernos de Saúde Pública, vol. 9, $\mathrm{n}^{\circ}$ 1, p. 65-78 março de 1993.

NOVAES, R. Juventude, conflito e solidariedade. Comunicações do ISER. № 50. Ano 17, 1998.

$\mathrm{N}^{\mathrm{0}}$ 57. Ano 21, 2002.

e Mello, C. Jovens do Rio: circuitos, crenças e acessos. Comunicações do ISER.

. "Polícia, polícias: as percepções dos jovens". In: O Galo e o Pavão.

Comunicações do ISER. N ${ }^{\circ}$ 58. Ano 22, 2003.

QUEIROZ, M. I. P de. Variações sobre a técnica de gravador no registro da informação viva.

São Paulo: T. A. QUEIROZ EDITOR. 1991.

RAMOS, S. "Geografia da Dura". www.cufa.com.br. 2003.

RINALDI, A. A. Marginais, delinquentes e vitimas: um estudo sobre a representação da categoria favelado no tribunal do júri da cidade do Rio de Janeiro. In: Um século de favela. Zaluar, A \& Alvito, M (orgs). $3^{\mathrm{a}}$ ed. Rio de Janeiro: Editora FGV, 2003.

SANSONE, L. Fugindo para a força: cultura corporativista e "cor" na Polícia Militar do Estado do Rio de Janeiro. Estudos Afro-Asiáticos, Ano 24, n³, 2002, p. 513 - 532.

SOARES, L. E. Violência e Política no Rio de Janeiro. Relume Dumará, 1996.

VELHO, G. A Utopia Urbana: um estudo de antropologia social. Rio de Janeiro: Zahar Editores. 1973

Projeto e metamorfose: antropologia das sociedades complexas. $2^{\circ}$ Edição. Rio de Janeiro: Jorge Zahar Editor. 1999.

ZALUAR, A. A Máquina e a Revolta. Brasiliense. 1985

Recebido em: 27/03/2015

Aprovado em: 10/06/2015 